\title{
CHARACTERIZATION OF KACANG GOAT SKIN PEPSIN SOLUBLE COLLAGEN (PSC) AND THEIR POTENCY AS AN ANTIOXIDANT
}

\author{
Rina Wahyuningsih ${ }^{1)}$, Rusman $^{2)}$, Nurliyani $^{2)}$, Abdul Rohman $^{3)}{ }^{4)}$, Nanung Agus Fitriyanto ${ }^{2)}$, Yuny Erwanto*2) ${ }^{4)}$ \\ ${ }^{1)}$ Research Division for Natural Product Technology-Indonesian Institute of Sciences (LIPI) Yogyakarta, \\ Indonesia \\ ${ }^{2)}$ Department of Animal Products Technology, Faculty of Animal Science, Univesitas Gadjah Mada, \\ Bulaksumur, Yogyakarta 55281 \\ 3) Department of Pharmaceutical Chemistry, Faculty of Pharmacy, Univesitas Gadjah Mada, Bulaksumur, \\ Yogyakarta 55281 \\ 4) Institute for Halal Industry \& System, Universitas Gadjah Mada, Jl. Kaliurang Km. 4,5 Yogyakarta 55281 \\ *Corresponding Email: yunyer@ugm.ac.id
}

Submitted 16 February 2021; Accepted 31 May 2021

\begin{abstract}
Collagen have been interesting material for many utilization such as food, pharmaceutical and cosmetic in various products and target administration, consequently collagen should be prepared as well as type of application. The objective of this research is to prepare collagen from goat skin and investigate the character and their potency as an antioxidant. Kacang goat skin aged 2 years was used for collagen production. Small slice skin was extracted by curing with $0.1 \%$ (w/v) pepsin in acetic acid $0.5 \mathrm{M}$, for 24,48 , dan $72 \mathrm{~h}$ at $4^{\circ} \mathrm{C}$. The variables observed were molecular weight by Sodium dodecyl sulfate polyacrylamide gel electrophoresis (SDS PAGE), microstructure using scanning electron microscope, thermal stability by differential scanning calorimetric, and the antioxidant potency through 2,2-diphenyl-1-picrylhydrazyl $(\mathrm{DPPH})$ inhibition analysis. The result showed the molecular weight range from $25 \mathrm{kDa}$ to 180 $\mathrm{kDa}$, microstructure showed the collagen fibril crosslink, collagen start to denature at $62,28^{\circ} \mathrm{C}$, highest dissolved with $1 \% \mathrm{NaCl}$ concentration and has highest DPPH inhibition at $60 \mathrm{~min}$ after hydrolysis. In conclusion, pepsin soluble collagen derived from kacang goat skin has antioxidant capacity and could be used in some applications.
\end{abstract}

Keywords: Antioxidant activity; characteristic; collagen; goat skin. 


\section{INTRODUCTION}

Collagen is one of the most important abundant single protein in the body of vertebrate animals because constituting 30\% of total proteins was represented collagen (Bhatnagar et al. 1999; Grover, Cameron, and Best 2012). In the body cells, collagen is used for structural integrity, improving strength and resistance in tissues (Woo et al., 2008). Collagen has 28 variants different types (types I-XXVIII). Type 1 collagen has many functions in the body, such as to biomaterial in wound dressing systems, in human used to implants of tissue engineering, and to drug delivery systems (Lee, Singla, and Lee 2001; (Friess, 1998). One of the type 1 collagen was many found in skins from animal tissues. Study of collagen the most used skin from fish, bovine, and pig skin.

Using collagen from bovine and pig skin has many carries potential risks such as some disease bovine spongiform encephalopathy (BSE) and religious problems (Jongjareonrak et al. 2005; Klompong et al. 2007). Alternative of a raw material to production of collagen must be to find different sources. So far study of collagen from goat skin is very limited. Object this study of collagen is using Indonesian local kacang goat skin which has a high population in Indonesian.

Method of isolation collagen from skin was extraction with using chemical methods and enzymatic methods. Extraction of collagen using chemical methods with acetic acid has low produce yield so to maximise produce of collagen yield was using enzymatic methods. One of the enzym used to extraction of collagen is pepsin. Pepsin is enzyme can hydrolysis the non collagenous proteins and reduce of the antigenicity (Benjakul, Nalinanon, and

*Corresponding author:

Yuny Erwanto

Email: yunyer@ugm.ac.id

Department of Animal Products Technology,

Faculty of Animal Science, Univesitas Gadjah

Mada, Bulaksumur, Yogyakarta 55281
Shahidi, 2012; Regenstein and Zhou, 2007). The objective of this study was to isolation of collagen from new source with using Indonesian local kacang goat skin and extracted with enzymatic process. Enzyme used to extraction collagen is pepsin. Collagen have been interesting material for many utilization such as food, pharmaceutical and cosmetic in various products and target administration, consequently collagen should be prepared as well as type of application. The objective of this research is to prepare collagen from goat skin and investigate the character and their potency as an antioxidant. The variables observed were molecular weight by SDS PAGE, microstructure using scanning electron microscope, thermal stability by differential scanning calorimetric, and the antioxidant potency through DPPH inhibition analysis.

\section{MATERIALS AND METHODS}

\section{Materials}

Indonesia Local kacang goat skin, sodium hydroxide and sodium chloride were purchased from Merck KgaA (Germany), acetic acid was purchased from SigmaAldrich (Germany), pepsin from porcine gastric mucosa was purchased from Merck (Germany), DPPH (1,1-diphenyl2picrylhydrazyl), methanol, sodium hydroxide was purchased from Merck Kga (Germany), and trichloroacetic acid (TCA).

\section{Methods \\ Extraction of collagen}

One hundred grams of skin was precisely weighed. Small slice skin was extracted by curing with $0.1 \%(\mathrm{w} / \mathrm{v})$ pepsin in acetic acid $0.5 \mathrm{M}$, for 24,48 , dan $72 \mathrm{~h}$ at $4^{\circ} \mathrm{C}$. The extract was filtered with Whatman No.1 paper. The collagen was precipitated

\section{How to cite:}

Wahyuningsih, R., Rusman., Nurliyani., Rohman, A., Fitriyanto, N. A., \& Erwanto, Y. (2021). Characterization of Kacang Goat skin Pepsin Soluble Collagen (Psc) and Their Potency as an Antioxidant. Jurnal Ilmu dan Teknologi Hasil Ternak (JITEK), 16 (2), 75-83 
by adding $\mathrm{NaCl}$ at final concentration of $2.6 \mathrm{M}$. The pellet was collected by centrifuging at $7000 \mathrm{~g}$ for $30 \mathrm{~min}$ at $4^{\circ} \mathrm{C}$ and then re-dissolved in $0.5 \mathrm{M}$ acetic acid. The resulting solutions were dialyzed against $0.1 \mathrm{M}$ acetic acid for $24 \mathrm{~h}$ with a change of solution once per $3 \mathrm{~h}$, and finally, a change used distilled water sequentially. The collagen was obtained by freeze-drying.

\section{SDS-polyacrylamide gel electrophoresis (PAGE)}

Electrophoresis patterns were measured by using method of Laemmli (1970). The lyophilized of collagen was dissolved with 0,5 M Tris $\mathrm{HCl}$ buffer $\mathrm{pH} 6.8$ to make a $3 \mathrm{mg} / \mathrm{ml}$. The sample was addes loading dye at ratio 1:1 and heated for $2 \mathrm{~min}$. Polyacrylamide gel was prepared with $7.5 \%$ gradient gel and $4 \%$ stacking gel. The sample solutions were loaded into each gel and electrophoresed for about $2 \mathrm{~h}$ at a constant voltage of $110 \mathrm{~V}$. Gel after eletrophoresis was stained (50\% methanol, $40 \% \mathrm{H} 2 \mathrm{O}, 10 \%$ acetic acid, $1 \%$ briliant blue) destained with $50 \%$ methanol, $40 \% \mathrm{H} 2 \mathrm{O}$, and $10 \%$ acetic acid. Finnaly gel was solution change with $10 \%$ acetic acid.

\section{Scanning electron microscopy (SEM)}

The samples were coated with palladium for about $8 \mathrm{~min}$ with the sputtering system (JEOL. JEC-3000PC). The image was taken by using a scanning electron microscopy from JEOL (JSM6510LA) under vacuum at $20 \mathrm{kV}$ with a magnification of $100 \mathrm{x}$ and $1000 \mathrm{x}$ was applied.

\section{Differential scanning calorimetry (DSC)}

DSC studies were done using the DSC-60 Plus (Shimadzu) which was calibrated for temperature and enthalpy using indium as the standard. Sampel PSC was accurately weighed into aluminum pans, hermetically sealed and scanned from 0 to $300^{\circ} \mathrm{C}$. An empty sealed aluminium pan was used as the reference. The maximum transaction temperature $\left(\mathrm{T}_{\max }\right)$ was recorded as the peak temperature.

\section{Solubility of collagen with different $\mathrm{NaCl}$ concentrations}

The solubilities of collagen samples was determined by the method of Montero, Jiménez-Colmenero, and Borderìas (1991) with a slight modification. The sample was dissolved in $0.5 \mathrm{M}$ acetic acid to obtain a final concentration of $3 \mathrm{mg} / \mathrm{ml}$ and the mixtures was stirred at $4^{\circ} \mathrm{C}$ for $24 \mathrm{~h}$. Thereafter, all the mixtures was centrifuged at $5000 \mathrm{~g}$ for $15 \mathrm{~min} 4^{\circ} \mathrm{C}$ and the supernatants was used for solubility study. Supernatants was mixed $5 \mathrm{ml}$ of $\mathrm{NaCl}$ in $0.5 \mathrm{M}$ acetic acid at various concentrations to give the final concentrations of $1 \%, 2 \%$, $3 \%, 4 \%, 5 \%$, and $6 \%$. The mixturewas stirred continuously at $4^{\circ} \mathrm{C}$ for $30 \mathrm{~min}$, followed by centrifuging at $10,000 \mathrm{~g}$ for $60 \mathrm{~min}$ at $4^{\circ} \mathrm{C}$. Protein content in the supernatant was measured and the relative solubility was calculated as previously described.

\section{DPPH radical scavenging activity}

DPPH radical scavenging activity of PSC hydrolysate was determined using method based (Jeevithan et al., 2015) with slight modification. Sample solution $4.5 \mathrm{mg} / \mathrm{ml}$ was mixde with $500 \mu \mathrm{l}$ of methanol and $125 \mu 10.02 \%$ (w/v) of DPPH in $99.5 \%$ methanol. The mixture was shaken and incubated in the dark place at $60 \mathrm{~min}$. Solution was measured of absorbance at $517 \mathrm{~nm}$ using spectrofotometer. The ascorbic acid as a positive control and all determinations were based on the means of three measurements. The calculation of DPPH radical scavenging activity was calculated as follows:

Radical scavenging activity $=\left[\left(\right.\right.$ A blank $-{ }_{\mathrm{A}}$ sample $) / \mathrm{A}$ blank X 100 $]$

Where ${ }_{\mathrm{A}}$ blank $=$ absorbance of the control, ${ }_{\mathrm{A}}$ sample $=$ absorbance of the sample 


\section{RESULT AND DISCUSSION}

\section{Electrophoretic pattern of PSC from Indonesian local kacang goat skin by SDS-PAGE}

Electrophoretic patterns of step by step procesing PSC from Indonesian local kacang goat skin were measured by SDSPAGE and compared in Fig. 1. The protein pattern each isolation process PSC had two $\alpha$ chain ( $\alpha 1$ and $\alpha 2), \beta$, and $\gamma$-component. The molecular weight range from $25 \mathrm{kDa}$ to $180 \mathrm{kDa}$. PSC from Indonesian local kacang goat skin has molecular mass lower than that of PSC from raw material others. PSC from Nothern pike (Esox lucius) had molecular mass about $118 \mathrm{KDa}(\alpha 1)$ and $108 \mathrm{KDa}(\alpha 2)$ (Kozlowska et al., 2015).

Beside it, other study of PSC from grass carp (Ctenopharyngodon idella) had molecular mass approximately $120 \mathrm{KDa}$ for $\alpha 1$ and $100 \mathrm{KDa}$ for $\alpha 2$ (Liu et al., 2015). PSC in this study had small molecular weight because the extraction process in $38^{\circ} \mathrm{C}$ higher than that extraction process of other raw materials. In low temperature, the collagen extract from goat skin become to a gel which difficult to filter process. PSC had significally lower proportions of crosslinked component and smaller molecular weight (Liu et al., 2015).

Pepsin was remove of all the crosslinked region at the telopeptide of tropocollagen, $\beta$-, and $\gamma$-chain without the effecting structural integrity of super triplehelix chain (Kittiphattanabawon et al., 2010). Molecular weight is related to thermal stability. According to (Zhang et al., 2012). Duan et al. 2009 stated that collagen which has a high molecular weight will have a more stable heat resistance compared to collagen which has a low molecular weight.

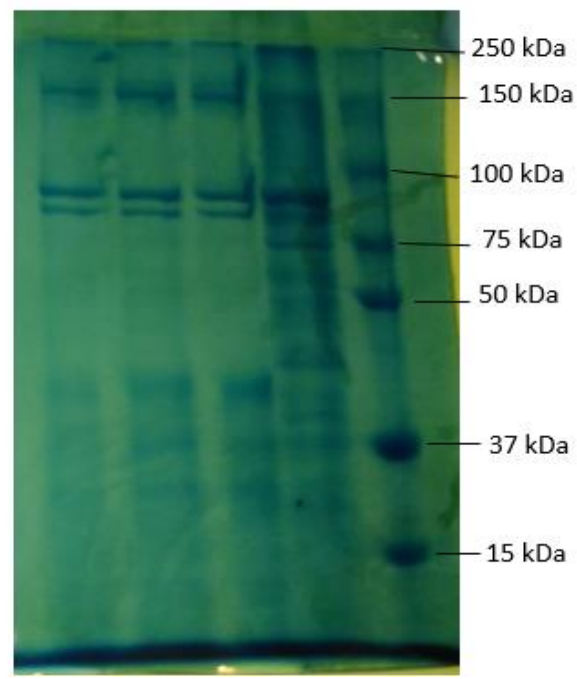

Figure 1. SDS-PAGE pattern of PSC from Indonesian local kacang goat skin on $7.5 \%$ gradient gel and $4 \%$ stacking gel.

\section{Scanning electron microscopy}

The lyophilized of PSC from Indonesian local kacang goat skin had a microstructure showed the collagen fibril crosslink. Structure of collagen from Indonesian local kacang goat skin can showed in this below Fig 2. According to (Jaswir et al., 2011), the use of acetic acid as a solution in extraction of collagen can be cause the skin to expand due to water penetration into the skin structure, so that in condition $\mathrm{H}^{+}$ions will be increase and water into the skin structure through electrostatic forces between polar groups or hydrogen bonds between polar groups and negative atoms. Swelling of the skin structure is very affected on the full structure of the fiber into the procolagen tropocolagen fiber. The increasing swelling of collagen was caused by increases solubility from hydrogel of collagen. The separation of collagen fibre structure was affected from swelling of the 
skin structure and can be interfere the noncovalent bond of collagen. The breakdown of the reticular tissue and elastin tissue was causing collagen swelling at low $\mathrm{pH}$ increasing by breaking intermolecular

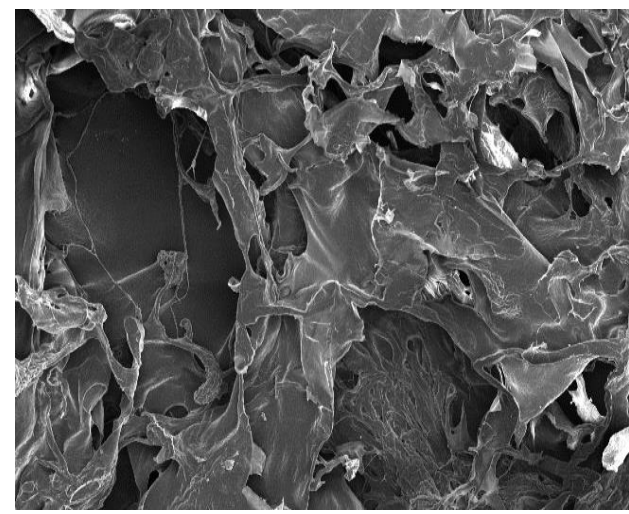

(a) interactions and hydrogen bonds. The cohesion of protein molecules can be reduced breaking intermolecular interaction between collagen fibrils and acid solutions (Suparno \& Prasetyo, 2019).

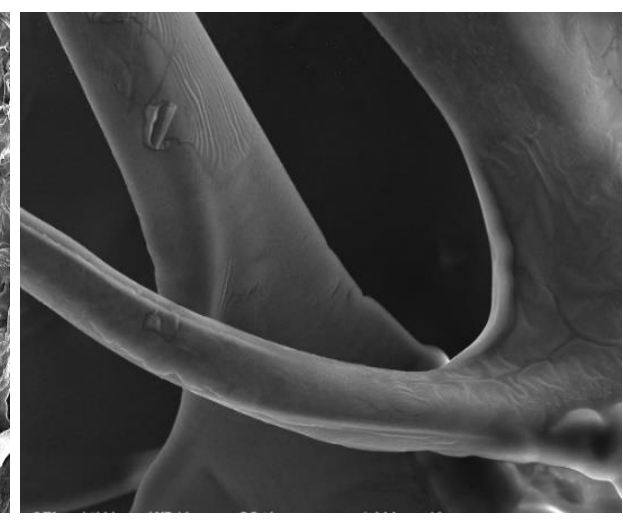

(b)

Figure 2. SEM of PSC from Indonesian local kacang goat skin. Scale bar $=100 \mu \mathrm{m} \times 100$; (b) scale bar $=10 \mu \mathrm{m} \times 1000$

\section{Differential scanning calorimetry}

Thermal stability of collagen in lyophilized collagen was examined using differential scanning calorimetry (DSC) analysis. DSC is measurement of the thermal denaturation of protein between sample and reference zone (Sionkowska et al., 2015). During the heating process of collagen in a nitrogen, DSC curve is formed. DSC curve of PSC from Indonesian local kacang goat skin is shown in Fig 3. Collagen in this study start to denature at $62.28^{\circ} \mathrm{C}$. Thermal analysis functions to determine the thermodynamic properties and character of the material as a function of temperature based on changes in physical and chemical properties (Petrovič et al., 2011). DSC is one of the thermal analyzes used to measure the difference in heat flow in the sample and the transition phases, namely glass transition (Tg), melting point (Tm), and temperature (Td) in the polymer. The first peak is related to temperature when denatured collagen and water are bound in protein molecules. The second exothermic peak illustrates the change in the structure of the complex part of collagen into a completely reconstructed protein kimia (Klančnik et al., 2010).

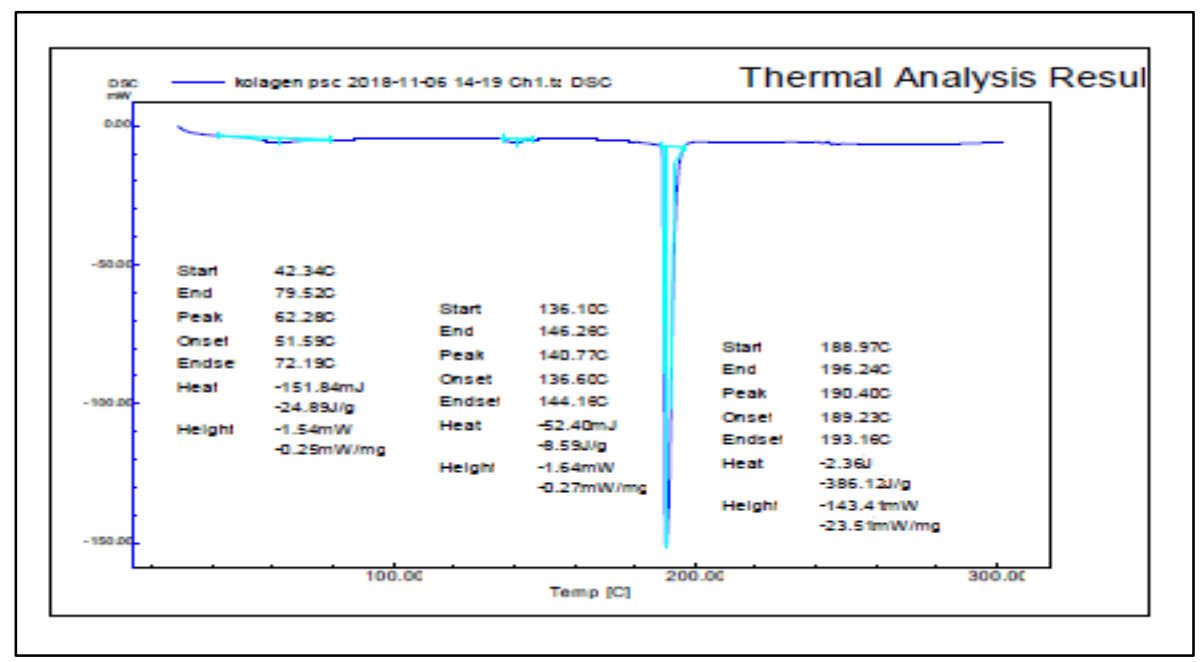

Figure 3. Differential scanning calorimetry collagen from Indonesian local kacang goat skin 


\section{Solubility of collagen with different $\mathrm{NaCl}$ concentrations}

The amount of dissolved collagen is also greatly influenced by the collagen deposition process. Collagen can be deposited using $\mathrm{NaCl}$. The purpose of the addition of salt with high concentrations is the occurrence of salting out, which means that salt can bind water so that the aggregation of proteins occurs and the protein experiences precipitation. This can occur because the ionic strength of salt is higher than protein so water is easily bound. Decreasing the amount of water that is bound to proteins causes protein to easily settle (Winarno, 2008). Solubility of collagen from Indonesian Local kacang goat skin with different $\mathrm{NaCl}$ concentration was shown Fig 4. Collagen in this study has highest dissolved with $1 \% \mathrm{NaCl}$ concentration which is $0.79 \pm 0.07 \mathrm{mg} / \mathrm{ml}$. Collagen solubility tends to decrease with increasing concentration of $\mathrm{NaCl}$ given. Increased $\mathrm{NaCl}$ concentration causes protein solubility in the solution to decrease, this can occur because of an increase in hydrophobic-hydrophobic interactions in the solution that causes water molecules and salt ions to compete with each other and aggregation occurs so that the protein precipitates (settles) (Bae et al. 2008 and Jongjareonrak et al. 2005).

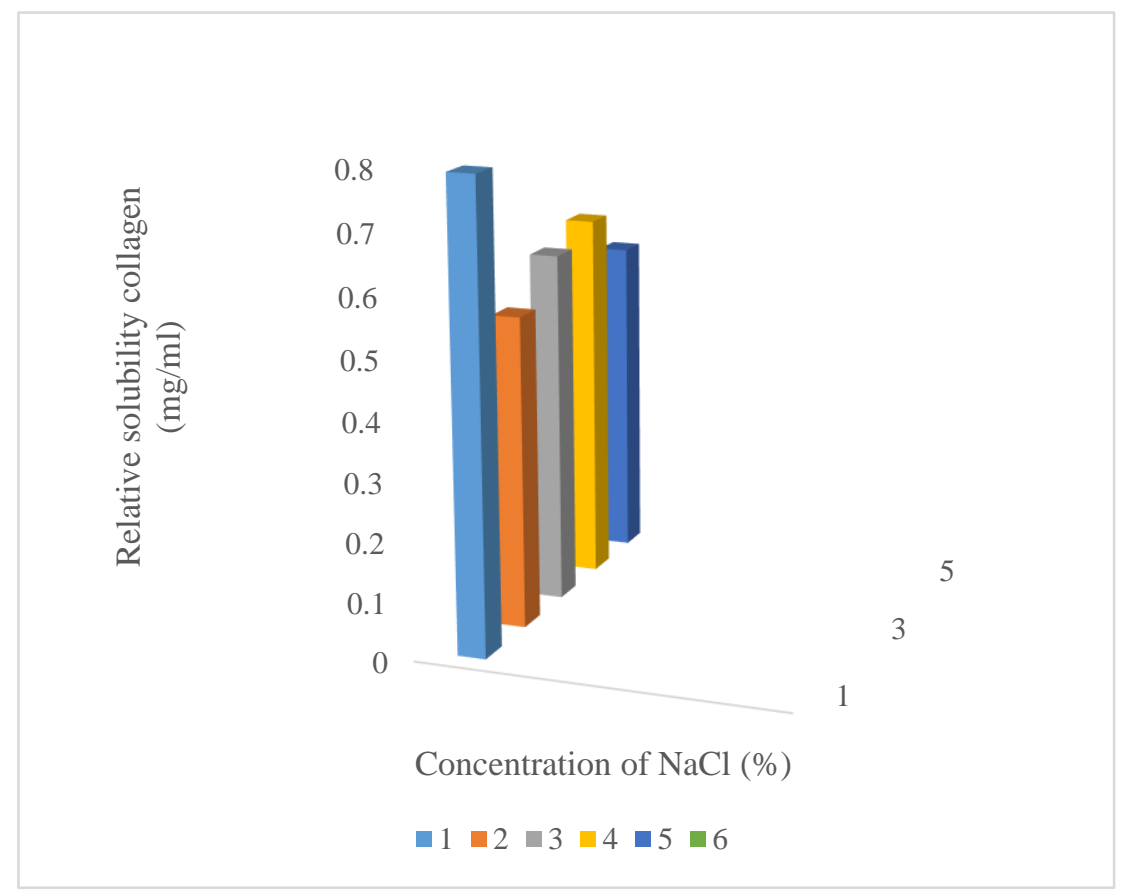

Figure 4. Solubility of collagen from Indonesian Local kacang goat skin in $0.5 \mathrm{M}$ acetic acid with different $\mathrm{NaCl}$ concentration

\section{Radical scavenging activity of collagen}

Radical scavenging activity from Indonesian Local kacang goat skin at different time hydrolysis was shown in Fig 5. Statistical analysis to radical scavenging activity with DPPH using SPSS 16.0 factorial complete randomized design model with 3 replications.

Collagen in this study also has highest DPPH inhibition at 60 min after hydrolysis with a value of $56.42 \%$ and IC50 value 4.64.
The antioxidant content in the sample can be measured by its antioxidant activity by looking at its ability to inhibit DPPH radical inhibitory activity which is a stable free radical in methanol and in the oxidized form has a strong absorption at a wavelength of $517 \mathrm{~nm}$.

DPPH free radicals are able to form stable diamagnetic molecules by receiving electrons or hydrogen radicals from other compounds (Gutteridge \& Halliwell, 2000). 
According to Molyneux (2004), antioxidant properties based on IC50 values are divided into 4 , namely the IC50 value $<50 \mathrm{ppm}$ has very strong antioxidant properties, IC50 50 to $100 \mathrm{ppm}$ means it has strong antioxidant properties, IC50 100 to $150 \mathrm{ppm}$ means it has moderate antioxidant properties, and IC50 150 to $200 \mathrm{ppm}$ means it has weak antioxidant properties. Based on these references it can be seen that ASC and PSC have very strong antioxidant properties (IC50 values $<50 \mathrm{ppm}$ ).

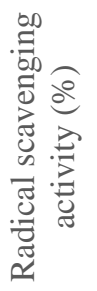

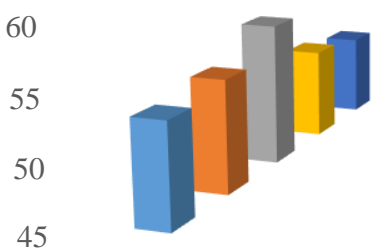

Time of hydrolysis $(\mathrm{min})$ - $0 \square 30-60-90 \square 120$

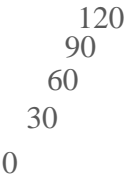

Figure 5. Radical scavenging activity from Indonesian Local kacang goat skin at different time hydrolysis

\section{CONCLUSIONS}

This study investigated of characterizing collagen from kacang goat skin and the potency of antioxidant activity. Generally, kacang goat skin collagen prepared by pepsin in acetic acid has proper character in some application, example using as cosmetic and pharmaceutical industry, carriers in the meat processing, edible film and coatings of products. Therefore, there is a possibility of collagen from Kacang goat skin as an alternative source of other collagen for industrial purposes.

\section{ACKNOWLEDGMENT}

The research work was supported by DIKTI Ministry of Research, Technology and Higher Educations Indonesia with contract No: 4586/UN1-III/LT/DITLIT/2016.

\section{REFERENCES}

Bae, I., Osatomi, K., Yoshida, A., Osako, K., Yamaguchi, A., \& Hara, K. (2008). Biochemical properties of acid-soluble collagens extracted from the skins of underutilised fishes. Food Chemistry, 108(1), 49-54. https://doi. org/10.1016/j.foodchem.2007.10.039

Benjakul, S., Nalinanon, S., \& Shahidi, F. (2012). Fish collagen. Food Biochemistry and Food Processing, Second Edition, 365-387. https://doi. org/10.1002/9781118308035.ch20

Bhatnagar, R. S., Gough, C. A., Qian, J. J., \& Shattuck, M. B. (1999). Fine structure of collagen: Molecular mechanisms of the interactions of collagen. Proceedings of the Indian Academy of Sciences-Chemical Sciences, 111(2), 301.

Duan, R., Zhang, J., Du, X., Yao, X., \& Konno, K. (2009). Properties of collagen from skin, scale and bone of carp (Cyprinus carpio). Food Chemistry, 112(3), 702-706. https:// doi.org/10.1016/j.foodchem.2008.06. 020

Friess, W. (1998). Collagen-biomaterial for drug delivery. European Journal of Pharmaceutics and Biopharmaceutics, 45(2), 113-136. https://doi.org/10.10 16/S0939-6411(98)00017-4

Grover, C. N., Cameron, R. E., \& Best, S. M. (2012). Investigating the morphological, mechanical and 
degradation properties of scaffolds comprising collagen, gelatin and elastin for use in soft tissue engineering. Journal of the Mechanical Behavior of Biomedical Materials, 10, 62-74. https://doi.org/ 10.1016/j.jmbbm.2012.02.028

Gutteridge, J. M. C., \& Halliwell, B. (2000). Free radicals and antioxidants in the year 2000: a historical look to the future. Annals of the New York Academy of Sciences, 899(1), 136147. https://doi.org/10.1111/j.174966 32.20 00.tb06182.x

Jaswir, I., Monsur, H. A., \& Salleh, H. M. (2011). Nano-structural analysis of fish collagen extracts for new process development. African Journal of Biotechnology, 10(81), 18847-18854. https://doi.org/10.5897/AJB11.2764

Jeevithan, E., Jingyi, Z., Wang, N., He, L., Bao, B., \& Wu, W. (2015). Physicochemical, antioxidant and intestinal absorption properties of whale shark type-II collagen based on its solubility with acid and pepsin. Process Biochemistry, 50(3), 463-472. https:// doi.org/10.1016/j.procbio.2014.11.015

Jongjareonrak, A., Benjakul, S., Visessanguan, W., Nagai, T., \& Tanaka, M. (2005). Isolation and characterisation of acid and pepsinsolubilised collagens from the skin of Brownstripe red snapper (Lutjanus vitta). Food Chemistry, 93(3), 475484. https://doi.org/10.1016/j.foodche m.2004.10.026

Klančnik, G., Medved, J., \& Mrvar, P. (2010). Differential thermal analysis (DTA) and differential scanning calorimetry (DSC) as a method of material investigation Diferenčna termična analiza (DTA) in diferenčna vrstična kalorimetrija (DSC) kot metoda za raziskavo materialov. RMZ-Materials and Geoenvironment, 57(1), 127-142.

Klompong, V., Benjakul, S., Kantachote, D., \& Shahidi, F. (2007). Antioxidative activity and functional properties of protein hydrolysate of yellow stripe trevally (Selaroides leptolepis) as influenced by the degree of hydrolysis and enzyme type. Food Chemistry, 102(4), 1317-1327. https: //doi.org/10.1016/j.foodchem.2006.07 .016

Kozlowska, J., Sionkowska, A., \& Piechowicz, K. (2015). International Journal of Biological Macromolecules Northern pike (Esox lucius) collagen : Extraction , characterization and potential application. International Journal of Biological Macromolecules, 81, 220-227. https://doi.org/10.1016/j. ijbiomac.2015.08.002

Lee, C. H., Singla, A., \& Lee, Y. (2001). Biomedical applications of collagen. International Journal of Pharmaceutics, 221(1-2), 1-22. https://doi.org/10.1016/ S0378-5173(01)00691-3

Liu, D., Zhang, X., Li, T., \& Yang, H. (2015). Extraction and characterization of acid- and pepsinsoluble collagens from the scales, skins and swim-bladders of grass carp (Ctenopharyngodon idella). Food Bioscience, 9, 68-74. https://doi.org/ 10.1016/j.fbio.2014.12.004

Molyneux, P. (2004). The use of the stable free radical diphenylpicrylhydrazyl (DPPH) for estimating antioxidant activity. Songklanakarin J. Sci. Technol, 26(2), 211-219.

Montero, P., Jiménez-Colmenero, F., \& Borderìas, J. (1991). Effect of $\mathrm{pH}$ and the presence of $\mathrm{NaCl}$ on some hydration properties of collagenous material from trout (Salmo irideus Gibb) muscle and skin. Journal of the Science of Food and Agriculture, 54(1), 137-146. https://doi.org/10.10 02/jsfa.2740540115

Petrovič, D. S., Klančnik, G., Pirnat, M., \& Medved, J. (2011). Differential scanning calorimetry study of the solidification sequence of austenitic stainless steel. Journal of Thermal Analysis and Calorimetry, 105(1), 251-257. https://doi.org/10.1007/s10 
973-011-1375-2

Regenstein, J. M., \& Zhou, P. (2007).

Collagen and gelatin from marine byproducts. Maximising the Value of Marine By-Products, 279-303. https: //doi.org/10.1533/9781845692087.2.279

Sionkowska, A., Kozłowska, J., Skorupska, M., \& Michalska, M. (2015). International Journal of Biological Macromolecules Isolation and characterization of collagen from the skin of Brama australis. International Journal of Biological Macromolecules, 80, 605-609. https://doi.org/10.1016/ j.ijbiomac.2015.07.032

Suparno, O., \& Prasetyo, N. B. (2019). Isolation of collagen from chicken feet with hydro-extraction method and its physico-chemical characterisation.
IOP Conference Series: Earth and Environmental Science, 335(1), 12018.

Winarno, F. G. (2008). Kimia Pangan dan Gizi edisi terbaru. Embrio Biotekindo. Bogor.

Woo, J., Yu, S., Cho, S., Lee, Y., \& Kim, S. (2008). ARTICLE IN PRESS Extraction optimization and properties of collagen from yellowfin tuna ( Thunnus albacares) dorsal skin. 22, 879-887. https://doi.org/10. 1016/j.foodhyd.2007.04.015

Zhang, Y., Duan, X., \& Zhuang, Y. (2012). Purification and characterization of novel antioxidant peptides from enzymatic hydrolysates of tilapia (Oreochromis niloticus) skin gelatin. Peptides, 38(1), 13-21. https://doi.org /10.1016/j.peptides.2012.08.014 